\title{
DIAGNOSTIC AND PROGNOSTIC SIGNIFICANCE OF MICROBIAL FLORA IMBALANCE IN GINGIVAL BIOFILM
}

\author{
G.A. Loban, T.O. Petrushanko, V.V. Chereda, \\ *M.O. Faustova, M.M. Ananieva, Ya.O. Basarab \\ UKRAINIAN MEDICAL STOMATOLOGICAL ACADEMY, POLTAVA, UKRAINE
}

Background. Periodontal tissues inflammatory diseases are widespread among young people.

Objective. This study was aimed at elaborating the method to assess risks of periodontal inflammatory diseases and determining its efficacy depending on the state of dental tissues, gum tissues and sex.

Methods. The study included 182 students (93 men, 89 women) aged 19-29: 22 individuals had no lesions of hard dental tissues and no signs of periodontal disease; 51 individuals were found to have DMF index $<6$; 52 individuals - DMF index $\geq 6 ; 57$ individuals were diagnosed with chronic catarrhal gingivitis. Primary groups were formed in autumn; re-examination was carried in spring. The research participants were assessed for detection of risks of periodontal inflammatory disease by the method developes by the authors (Patent UA 54041).

Results. The study revealed that the risk of development of preiodontitis increases in individuals with high caries and gingivitis intensity. In spring, more individuals suffer from microbial imbalance in in the composition of gingival sulcus fluid and decrease in the mean stability coefficient value that indicates an increased risk of inflammatory periodontal disease development. Women were less likely to experience seasonal dysbiotic changes in the gingival sulcus fluid composition compared with men.

Conclusions. The method suggested for assessment of the risk of periodontal inflammatory diseases is of high informativeness. It allows clinicians detecting early pre-nosological signs of oral microbiocenosis imbalance that enhances the effectiveness of early diagnosis of inflammatory periodontal diseases.

KEY WORDS: biofilms; microflora; gingivitis; risk of morbidity.

\section{Introduction}

According to the recent reports, oral and dental health has significantly improved in most countries, but the prevalence of inflammatory diseases of periodontal disease is still high [7, $9,10]$. Inflammatory diseases of periodontal tissues are reported to be quite common among young population [7]. These diseases are in the focus of researchers and clinicians as they are a main cause of tooth loss as well as they increase risks of systemic pathologies even in young age. Therefore, early diagnosis of inflammatory gum diseases and prognosis of their outcomes are one of topical issues of contemporary dentistry.

The oral cavity is an ecological system harbouring various types of microorganisms forming a biofilm $[1,8,11,13]$. In the oral cavity, bacteria can be present in the planktonic state (e. g., in saliva) and can develop as colonies that adhere to organic structures and build up plaque, and are able to organize associations

*Corresponding author: Maria Faustova, Ukrainian Medical Stomatological Academy, 23 Shevchenko Street, Poltava 36011, Ukraine.E-mail: mashafaustova@ukr.net for joint survival. The colonies may develop their complex and unexpected distinct properties. According to the current interpretation, the bacterial plaque is called a biofilm, which is a specialized bacterial ecosystem that provides the viability and preservation of microbial species forming the biofilm and promotes their general population increase [14]. Moreover, biofilm is an independent and self-regulating biological system, far from being an amorphous association of different bacteria.

At present, early pre-nosological signs of the risk of inflammatory gum diseases are hardly diagnosed in dental practice. The relations between the early micro-ecological imbalance of the oral cavity and risk of gingival inflammation development are still unclear as well as the issues of gum disease prediction. The development of accessible and easy-to-use methods for early diagnosis and prediction of gum diseases and their progression in young age allows clinicians providing an evidencebased approach to choose the proper tactics in managing such patients. 
This study was aimed at elaborating the prognostic criteria to assess risks of periodontal inflammatory diseases and determining its efficacy depending on the state of dental tissues, gum tissues and sex.

\section{Methods}

182 students of a medical college aged 1929. 22 individuals ( 11 men and 11 women), who had no lesions of hard dental tissues and no signs of periodontal disease, made up the control group. 51 individuals ( 26 men, 25 women) were found to have DMF index $<6 ; 52$ individuals (27 men, 25 women) - DMF index 26; 57 individuals ( 29 men, 28 women) were diagnosed with chronic catarrhal gingivitis. Primary groups were formed in autumn (October-November); re-examination of the test groups was carried out in 6 months in spring (April-May).

The study was conducted in accordance with the Helsinki Declaration of the World Medical Association on the ethical principles for medical research involving human subjects [15]. Signed written informed consents to participate in research study were given by research project participants that was an indispensable condition for the inclusion of students in the study.

The research participants underwent standard dental clinical examination to determine caries intensity index (DMF index), oral hygiene index (Greene-Vermilion index) (OHI-S), PMA gingival index modified by C. Parma, Muhlemann bleeding index, Muhlemann-Saxer index (PBI), interdental hygiene index (HYG), complex periodontal index (CPI). All subjects were assessed for the risk of periodontal inflammatory disease by the method elaborated by the authors - the Patent (utility model UA 54041, published Information Bulletin) [2].

The method of assessment of the risks of periodontal inflammatory diseases development is: gingival fluid is obtained in 1-2 hours following tooth brushing with a sterile paper pin of $10 \mathrm{~mm}$ long, by inserting its end in the orifice of the gingival groove. When the paper pin gets soaked with the fluid of the gingival groove, it is placed in $0.1 \mathrm{ml}$ of sterile saline and washed thoroughly. After that this saline suspension of microorganisms is put onto degreased sterile slide with following drying, fixing, staining by Gram techniques. Immersion microscopy is used to count the number of Gram-positive cocci, Gram-negative cocci, Gram-positive rods, Gram-negative rods, Gram-negative spirilla as a percentage of total bacterial cells counted.

The stability coefficient (SC) is calculated by the ratio of the sum of the number of Grampositive cocci and Gram-positive rod-shaped microorganisms as percentage to the sum of the number of Gram-negative rods and Gramnegative spirilla as percentage. When the SC value equals $2-4$, this indicates the ecological balance between bacterial populations, prevalence of symbiotic stabilizing microbiota, and no risks of inflammatory periodontal disease. When the SC value is $>4$ (SC shift to the right), this points out an increase in the number of Gram-positive bacteria residing on the gum tissues. These microorganisms are constituents of the dental plaque and contribute to development of inflammatory response characteristic of gingivitis, that is, the risk of inflammatory periodontal diseases increases. When the SC value is $<2$ (SC shift to the left), this evidenced an increase in obligatory anaerobic Gram-negative rod-shaped bacteria (bacteroids) and spirilla that have periodontopathogenic effect, i.e., the risk of periodontitis development increases [2].

Statistical analysis of the findings obtained was carried out using the SPSS 17.0 and Microsoft Excel 2003 programs. The obtained quantitative indicators were processed by the methods of mathematical statistics with definition of mean values (M) and errors of mean values $(m)$ in the groups of individuals under the study. The statistically significance of differences between the investigated indicators was estimated by the Student's t-test criterion. For comparison of the particles in separate groups, $\chi^{2}$ criterion was used to determine the statistical significance of their differences.

\section{Results}

The assessment of the risk of inflammatory periodontal diseases that was carried out in the autumn has revealed the following. In the control group, the incidence rate of SC within the range of $2-4$ made up $95.5 \%$, in $4.5 \%$ of individuals there was a SC shift to the right (Fig. 1). The development of caries was accompanied by changes in the frequency structure of the SC gradations. In the individuals with DMF index $<6$, the number of people with $\mathrm{SC}=$ 2-4 decreased by $34.7 \%$; the SC shift to the left was observed to be as more often as by $29.4 \%$, and the frequency of the SC shift to the right increased by $5.3 \%\left(\chi^{2}=97042.761, p=0.0001\right)$. The increase in the caries intensity to DMF index $\geq 6$ 
was accompanied by a decrease in the number of individuals with SC $=2-4$ to $53.8 \% ; 25.0 \%$ of the subjects were found to have $\mathrm{SC}<2$, the number of individuals with SC shift to the right increased to $21.2 \%\left(\chi^{2}=71518240, p=0.0001\right)$. Among the patients with gingivitis, subjects with SC $<2(73.7 \%)$ and SC $>4$ (26.3\%) prevailed, while the patients with $\mathrm{SC}=2-4$ were not detected $\left(\chi^{2}=648866.373, p=0.0001\right)$.

The mean SC value decreased in the subjects with $D M F$ index $<6$ by $18.2 \%(2.92 \pm 0.18 \mathrm{vs}$. $3.57 \pm 0.11$ in control, $p=0.002$ ) and especially in patients with gingivitis, by $38.7 \%(2.19 \pm 0.20$, $\mathrm{p}=0.0005$ ).

The regularities of the frequency in detecting certain SC gradations and their absolute values did not depend on sex.

In spring, the frequency of detecting SC gradations depended on the condition of teeth and gums (Fig. 2). The number of individuals with dysbiotic shifts in the gingival fluid microbiota in comparison with the control group, increased in the individuals with DMF index $<6$ by $6.2 \%\left(\chi^{2}=3876.859, p=0.0001\right)$, in the individuals with DMF index $\geq 6$ by $16.8 \%\left(\chi^{2}=\right.$ $8653.959, p=0.0001$ ), and in the patients with gingivitis there was an increase by $59,1 \%$ $\left(\chi^{2}=13941.459, p=0.0001\right)$. The mean SC value in the individuals with caries did not differ from those in the control group $(2.54 \pm 0.16$ for DMF index $<6 ; 2.82 \pm 0.19$ for DMF index $\geq 6$ vs. $2.62 \pm 0.19$ for the control). The mean SC value in the individuals with catarrhal gingivitis was 1.6 times lower compared with the control $(1.67 \pm 0.17, p=0.0004)$.

In spring, compared to the fall, the frequency profile in all the study groups changed due to an increase in the number of individuals with SC shift to the left: in the control group, it increased by $40.9 \%\left(\chi^{2}=77307.546, p=0.0001\right)$, in the individuals with $D M F \geq 6-$ by $15.4 \%\left(\chi^{2}=17.484\right.$, $p=0.0001$ ), and in the individuals with catarrhal gingivitis - by $15.8 \%\left(\chi^{2}=7.329, p=0.007\right)$. The mean SC value decreased in the control group

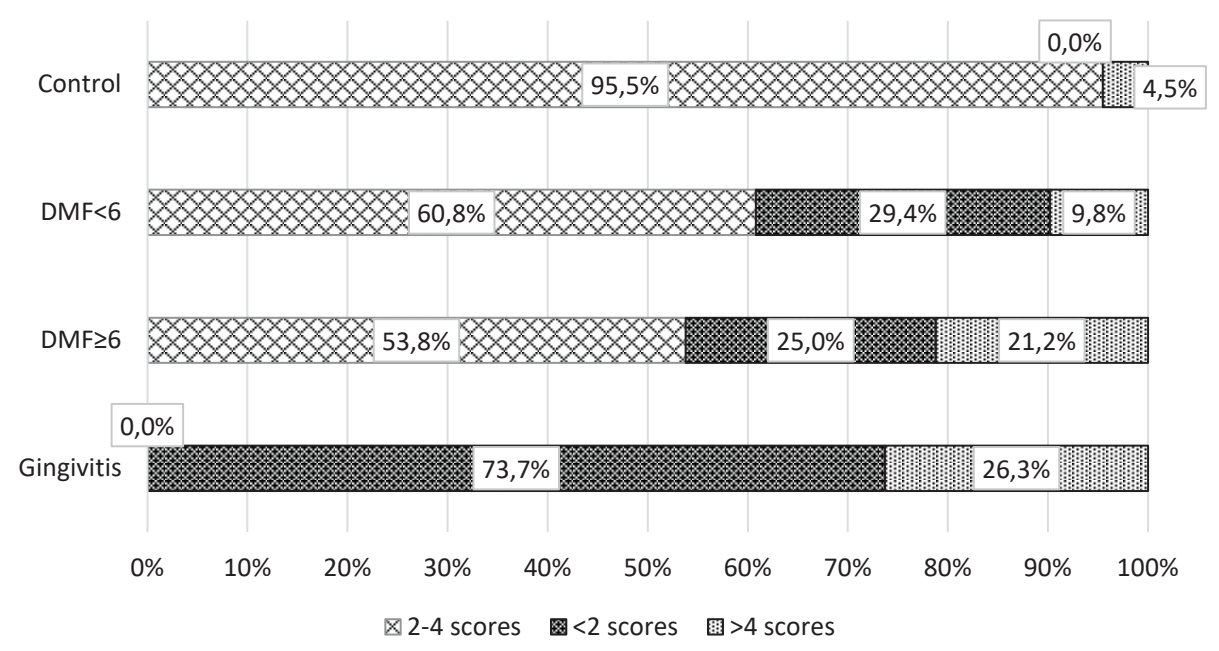

Fig. 1. Rate of SC gradations in adolescents in autumn.

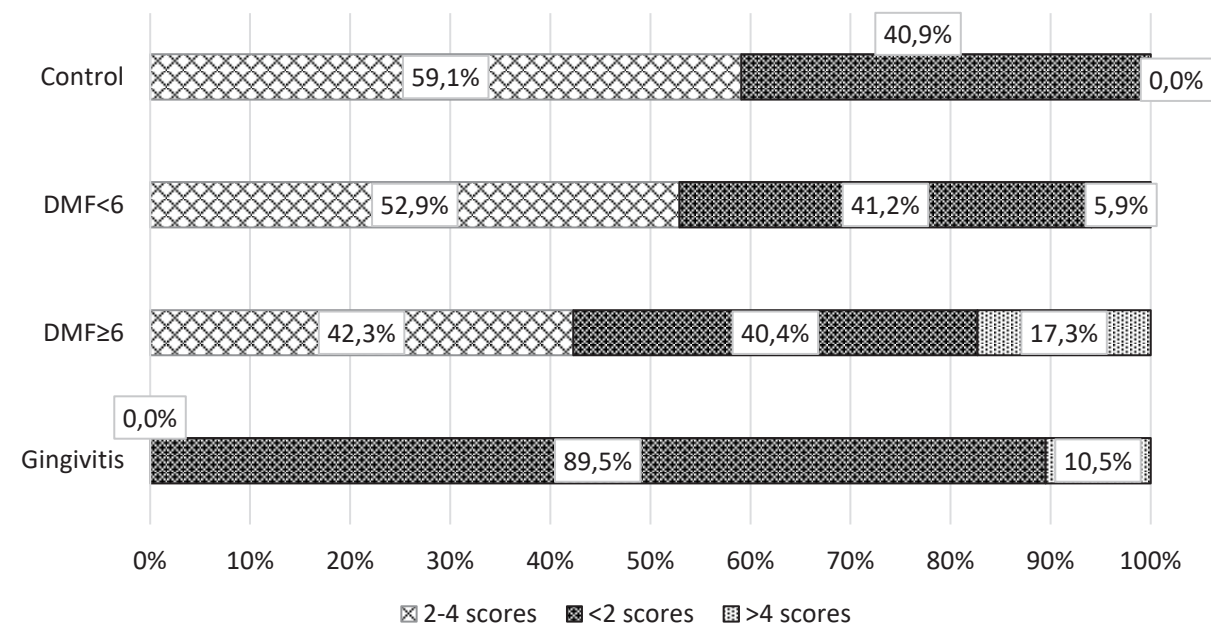

Fig. 2. Rate of SC gradations in adolescents in spring. 
in 1.4 times $(p=0.0001)$, and in the patients with gingivitis - in 1.3 times $(p=0.047)$.

In spring, in men and women, the SC frequency profile also depended on the dental status and was characterized by a significantly higher number of individuals with dysbiosis in the gingival sulcus biofilm in all the studied groups compared to the control. The mean SC value in men with gingivitis was 1.6 times lower than in the control group $(1.61 \pm 0.24$ versus $2.59 \pm 0.26$ in control, $p=0.019)$, while in women it did not differ significantly $(1.77 \pm 0.24$ vs. $2.64 \pm 0.27$ in the control).

In spring, in comparison with autumn, the number of persons with SC shift to the left increased in both men and women: in the control groups of men it increased by $45.5 \%$ $\left(\chi^{2}=22721.819, p=0.0001\right)$, in women - by $34.6 \%$ $\left(\chi^{2}=15994.909, p=0.0001\right)$; in men with DMF index $\geq 6$, it increased by $22.3 \%\left(\chi^{2}=6.9661\right.$, $\mathrm{p}=0.031$ ), in women with gingivitis - by $17.9 \%$ $\left(\chi^{2}=4.375, p=0.036\right)$. The mean SC value in the control groups decreased in men in 1.4 times $(2.59 \pm 0.26$ in the spring compared with $3.71 \pm 0.12$ in autumn, $p=0.002)$, and in women, it - in 1.3 times $(2.64 \pm 0.27$ in spring compared to $3.43 \pm 0.18$ in autumn, $p=0.028$ ).

In spring, male subjects showed gradations of SC $<2$ and SC $>4$ more often than female subjects, and in particular, in the male patients with high caries intensity, it was observed to be more frequent (by 26.4\%) $\left(\chi^{2}=8.397, p=0.015\right)$. The attained results testify that women are less likely to experience seasonal dysbiotic changes in the gingival sulcus biofilm.

In the individuals, whose gums were assessed as intact in autumn, the inflammation development in spring was detected: in the control group, there were 3 individuals with signs of inflammation (1 woman, 2 men) constituting $13.6 \%$ of the whole group, in the adolescents with DMF index $<6$, there were 16 individuals (9 men, 7 women) that made up $31.4 \%$ of the relevant group; and in the individuals with DFF index $\geq 6$, there were 21 patients (14 men, 7 women) that made up $40.4 \%$ of the individuals. The highest periodontal indexes were observed in the patients with catarrhal gingivitis, but in the patients with caries, their PMA, Muhlemann, and PBI indices were significantly higher than those of the control group. In the study group of patients with catarrhal gingivitis in spring, there was a tendency to increase in the periodontal indices, compared with the autumn. In particular, the PMA was $27.7 \pm 0.89 \%$ (compared with $0.91 \pm 0.51 \%$ in the control group), the Muhlemann index $1.45 \pm 0.057$ (in the control $0.02 \pm 0.013$ ), the PBI index $-0.91 \pm 0.034(0.01 \pm 0.006$ in the control group). In the patients with caries, PMA, Muhlemann and PBI indexes were also significantly higher than the controls. Thus, in persons with DMF $<6$ PMA, this index was in 3.9 times higher in the control group $(p<0.05)$, the Muhlemann index - in 3.0 times $(p<0.05)$, and the PBI index in 6.0 times $(p<0.05)$. In the patients with DMF $\geq 6$, the periodontal indexes were even higher than the corresponding control group values, namely: PMA - in 4.6 times $(p<0.05)$, Muhlemann index - in 4.0 times $(p<0.05)$, the PBI index - in 7.0 times $(p<0.05)$.

In the study group of patients with catarrhal gingivitis in spring a tendency to increase in the periodontal indices was observed, compared with the autumn season.

In men and women, in spring, the changes in indexes compare to the groups by dental status and by season had the same features as in the groups without regard to sex.

\section{Discussion}

The study revealed an increase in the incidence of inflammatory processes in periodontal tissues of adolescents in spring. A number of reports have emphasized polyetiological nature of periodontal diseases. And in addition to that, inflammatory reactions provoked by gingival biofilm microflora are established to greatly contribute to development of periodontal diseases $[5,6,12]$. The suggested criteria have demonstrated an increase in the incidence of dysbiosis in the gingival biofilm in adolescents in spring that, in our opinion, determine an increase in the incidence of gingivitis in spring compared with autumn.

The quantitative and specific composition of the oral microbial flora of each healthy individual is relatively stable, since there are a number of factors that maintain its constancy. The most important factor in maintaining the stability of the oral microbial composition is the antagonism inherent in the resident microbial flora relative to pathogenic and opportunistic microorganisms, when a stable microbial community crowds out pathogenic agents from the oral cavity [13].

Compensatory properties of symbiotic microbial flora are far from being limitless and under the influence of various factors, the dynamic equilibrium between a normal and pathogenic flora may be disrupted $[3,4]$. For instance, the disorders of swallowing, chewing 
and salivation always lead to an increase in the number of pathogenic microorganisms in the oral cavity. As a result, sharp suppression of normal microbial flora representatives occurs, i.e. dysbiosis develops, that means qualitative and/or quantitative changes in the resident microbial flora resulting from the impact of various exogenous or endogenous factors on the body [5].

\section{Conclusions}

The suggested prognostic criteria for assessing the risk of periodontal inflammatory diseases are of high informativeness, they allow clinicians detecting early pre-nosological signs of oral microbiocenosis imbalance that enhances the effectiveness of early diagnosis of inflammatory periodontal diseases, and can be used as a marker to evaluate the degree of body adaptation to the environment factors. The imbalance of indigenous and periodontopathogenic microbial flora has a significant impact on the oral status of adolescents regardless of sex. The risk of periodontitis development increases in individuals with caries severity and gingivitis intensity. In spring, more individuals were identified to have microbial imbalance in the composition of gingival sulcus fluid and a decrease in the mean stability coefficient that indicates an increase in the risk of inflammatory periodontal disease development. Women were less likely to experience seasonal dysbiotic changes in the gingival sulcus fluid composition compared with men.

In clinical dental practice early diagnosis of periodontal diseases and prediction of their development is significant for elaborating effective preventive measures. To predict the probable progression of the disease, taking into account the patterns of pathological processes and the course of the disease, the attained results require wider applying of mathematical analysis (correlation and regressive). Detection of a wide range of relations not only improves the effectiveness of personalized prediction of microecological imbalance in the oral cavity but also allows choosing and prescribing appropriate preventive therapy or start treatment at the right time.

\section{Funding}

This research received no external funding. Conflict of Interests

The authors declare no conflict of interest.

\section{Authors Contributions}

Loban' G.A. - conceptualization, methodology, project administration, writing - review \& editing; Petrushanko T.O. - methodology, project administration; Chereda V.V. - investigation, visualization; Faustova M.O. - formal analysis, writing - review \& editing; Ananieva M.M. - visualization, writing - original draft; Basarab Ya.O. - writing - original draft.

\title{
ДІАГНОСТИЧНЕ I ПРОГНОСТИЧНЕ ЗНАЧЕННЯ ДИСБАЛАНСУ МІКРОФЛОРИ ЯСЕННОЇ БІОПЛІВКИ
}

\author{
Г.А. Лобань, Т.О. Петрушанко, В.В. Череда, \\ М.О. Фаустова, М.М. Ананьєва, Я.О. Басараб \\ УКРАЇНСЬКА МЕДИЧНА СТОМАТОЛОГІЧНА АКАДЕМІЯ, ПОЛТАВА, УКРАЇНА
}

Вступ. Запальні захворювання тканин пародонта широко поширені серед молоді.

Мета. Це дослідження було спрямоване на розробку методу оцінки ризику запальних захворювань пародонта та визначення його ефективності залежно від стану тканин зубів та ясен і гендерного фактору.

Методи. Обстежено 182 студенти (93 чоловіків і 89 жінок) віком 19-29 років, з яких 22 особи не мали уражень твердих тканин зубів та пародонта, 51 особа з рівнем КПВ<6, 52 особи з рівнем КПВ $\geq 6$, 57 осіб з діагностованим хронічним катаральним гінгівітом. Первинні групи були сформовані восени, повторне обстеження проводилося навесні. Вусіх досліджуваних провели визначення стоматологічного статусу, виявлення ризику розвитку запальних захворювань пародонта здійснили за власною методикою (патент UA 54041).

Результати. Проведені дослідження показали, що ризик розвитку пародонтиту підвищується в осіб з високою інтенсивністю карієсу та гінгівітом. У весняний період року виявили більшу кількість осіб з дисбалансом біоплівки ясенної борозни та зниження середньої величини коефіцієнту сталості порівняно з осіннім сезоном, що свідчило про збільшення ризику розвитку запальних захворювань 
пародонта навесні. У жінок рідше спостерігали сезонні дисбіотичні зміни біоплівки ясенної борозни порівняно з чоловіками.

Висновки. Запропонований метод очінки ризику запальних захворювань пародонта має високу інформативність, дозволяє виявити ранні донозологічні порушення мікробіоценозу порожнини рота, що підвищує ефективність ранньої діагностики. запальних захворювань пародонта, і може бути використаний як маркер ступеня адаптації організму до факторів зовнішнього середовища.

КЛЮчОВІ СЛОВА: біоплівки; мікрофлора; гінгівіт; ризик захворювань.

\section{Відомості про авторів}

Лобань Галина Андріївна - доктор медичних наук, професор, завідувачка кафедри мікробіології, вірусології та імунології Української медичної стоматологічної академії, Полтава, Україна.

Петрушанко Тетяна Олексіївна - доктор медичних наук, професор, завідувачка кафедри терапевтичної стоматології Української медичної стоматологічної академії, Полтава.

Череда Вікторія Володимирівна - кандидат медичних наук, асистент кафедри терапевтичної стоматології Української медичної стоматологічної академії, Полтава.

Фаустова Марія Олексіївна - кандидат медичних наук, викладач кафедри мікробіології, вірусології та імунології Української медичної стоматологічної академії, Полтава, Україна.

Ананьєва Майя Миколаївна - кандидат медичних наук, доцент кафедри мікробіології, вірусології та імунології Української медичної стоматологічної академії, Полтава, Україна.

Басараб ярослав Олексійович - викладач кафедри мікробіології, вірусології та імунології Української медичної стоматологічної академії, Полтава, Україна.

\section{Information about the authors}

Loban' G. A. - MD, Ph.D., DSc, Head of Microbiology, Virology and Immunology Department, Ukrainian Medical Stomatological Academy, Poltava, Ukraine.

ORCID 000-0003-0055-7696, e-mail: galina.loban@gmail.com

Petrushanko T.O. - MD, Ph.D., DSc, Head of Therapeutic Dentistry Department, Ukrainian Medical Stomatological Academy, Poltava, Ukraine.

ORCID 0000-0002-1001-5404, e-mail: petrusankotatana@gmail.com

Chereda V. V. - PhD, Lecturer of Therapeutic Dentistry Department, Ukrainian Medical Stomatological Academy, Poltava, Ukraine.

ORCID 0000-0002-5823-9642, e-mail: viktoria.chereda@gmail.com

Faustova M. O. - PhD, Lecturer of Microbiology, Virology and Immunology Department, Ukrainian Medical Stomatological Academy, Poltava, Ukraine.

ORCID 0000-0001-5327-6324, e-mail: mashafaustova@ukr.net

Ananieva M. M. - MD, PhD, Associate Professor of Microbiology, Virology and Immunology Department, Ukrainian Medical Stomatological Academy, Poltava, Ukraine.

ORCID 0000-0001-9435-7622, e-mail: anfila@ukr.net

Basarab Ya. O. - MD, Lecturer of Microbiology, Virology and Immunology Department, Ukrainian Medical Stomatological Academy, Poltava, Ukraine.

ORCID 0000-0001-7644-0713, e-mail: basarab.yaroslav.doc@gmail.com

\section{References}

1. Kassebaum NJ, Smith AG, Bernabé E, Fleming TD, Reynolds AE, Vos T et al. GBD 2015 Oral Health Collaborators. Global, regional, and national prevalence, incidence, and disability-adjusted life years for oral conditions for 195 countries, 19902015: a systematic analysis for the global burden of diseases, injuries, and risk factors. J Dent Res. 2017; 96,4:380-7.

doi: $10.1177 / 0022034517693566$

2. Machado V, Botelho J, Amaral A, Proença L, Alves R, Rua J et al. Prevalence and extent of chronic periodontitis and its risk factors in a Portuguese subpopulation: a retrospective cross-sectional study and analysis of Clinical Attachment Loss. PeerJ. 2018; 24, 6, e5258.

doi: 10.7717/peerj.5258. eCollection 2018
3. Oppermann RV, Haas AN, Rösing CK, Susin C. Epidemiology of periodontal diseases in adults from Latin America. Periodontol 2000, 2015; 67, 1: 13-33. doi: $10.1111 /$ prd.12061

4. Nazarchuk OA, Paliy VG, Bereza BM, Yatsula OV, Zaderey NV, Gonchar OO, et al. The research of qualities of microflora from tooth-gingival sulcus in patients with gingivitis. Herald of Vinnytsia National Medical University. 2016; 2:370-375 [In Ukrainian].

5. Lof M, Janus MM, Krom BP. Metabolic Interactions between Bacteria and Fungi in Commensal Oral Biofilms. J Fungi (Basel). 2017;14,3,3, pii: E40. doi: 10.3390/jof3030040

6. Petrushanko TA, Chereda VV, Loban' GA. The relationship between colonization resistance of the oral cavity and individual-typological characteristics 
of personality: dental aspects. Wiad Lek. 2017;70,4: 754-7.

7. Rosier BT, Marsh PD, Mira A. Resilience of the Oral Microbiota in Health: Mechanisms That Prevent Dysbiosis. J Dent Res. 2018;97,4:371-80.

doi: 10.1177/0022034517742139

8. Faustova MO, Ananieva MM, Basarab YO, Dobrobolska OV, Vovk IM, Loban' GA. Bacterial factors of cariogenicity (literature review). Wiad Lek. 2018; 71,2: 378-82.

9. WMA declaration of helsinki - ethical principles for medical research involving human subjects. https://www.wma.net/policies-post/wma-declaration-of-helsinki-ethical-principles-for-medicalresearch-involving-human-subjects/

10. Chereda VV, Petrushanko TO, Loban' GA. A method for assessing the risk of inflammatory periodontal disease. Health Newsletter. Kyiv: Ukrmedpatentinform Ministry of Health of Ukraine. 2012;21,136:3. [In Ukrainian].

11. Ebersole JL, Dawson D, Emecen-Huja P, Nagarajan R, Howard K, Grady ME, et al. The periodontal war: microbes and immunity. Periodontol 2000. 2017;75,1:52-115.

doi: $10.1111 /$ prd.12222

12. Herrero ER, Fernandes S, Verspecht T, UgarteBerzal E, Boon N, Proost P et al. Dysbiotic Biofilms Deregulate the Periodontal Inflammatory Response. J Dent Res. 2018; 97,5:547-55.

doi: $10.1177 / 0022034517752675$

13. Rafiei M, Kiani F, Sayehmiri K, Sayehmiri F, Tavirani $M$ et al. Prevalence of Anaerobic Bacteria (P.gingivalis) as Major Microbial Agent in the Incidence Periodontal Diseases by Meta-analysis. J Dent (Shiraz). 2018; 19,3:232-42.

14. Ananieva MM, Faustova MO, Basarab IO, Loban' GA. Kocuria rosea, Kocuria kristinae, Leuconostoc mesenteroides as caries-causing representatives of oral microflora. Wiad Lek. 2017;70,2,2:296-8.

15. Ananieva M, Nazarchuk O, Faustova M, Basarab Y, Loban G. Pathogenicity factors of kocuria kristinae contributing to the development of periimplant mucositis. Mal J Med Health Sci. 2018;14,3: 34-8.
Received 05 September 2019; revised 11 October 2019; accepted 21 October 2019.

This is open access article distributed under the Creative Commons Attribution License, which permits unrestricted use, distribution, and reproduction in any medium, provided the original work is properly cited. 